
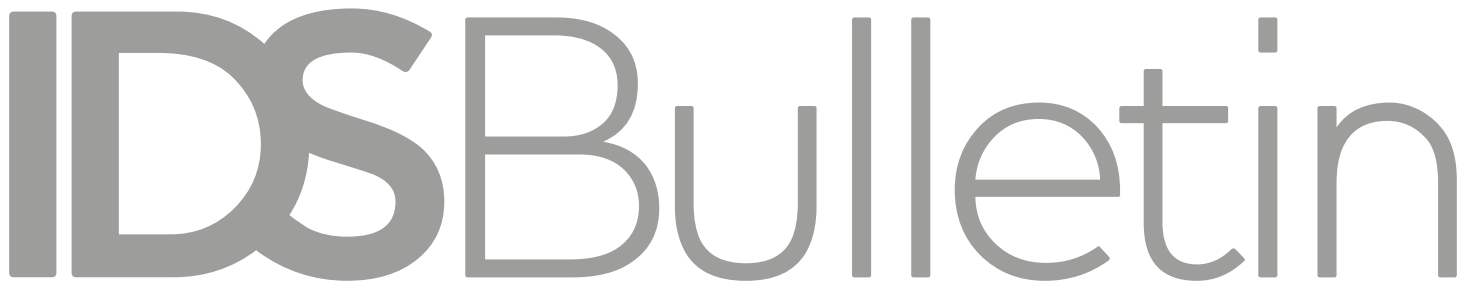

Transforming

Development Knouledge

Volume 49 | Number 3 | July 2018

\title{
EMERGING ECONOMIES AND THE CHANGING DYNAMICS OF DEVELOPMENT COOPERATION
}

Editors Jing Gu and Naohiro Kitano

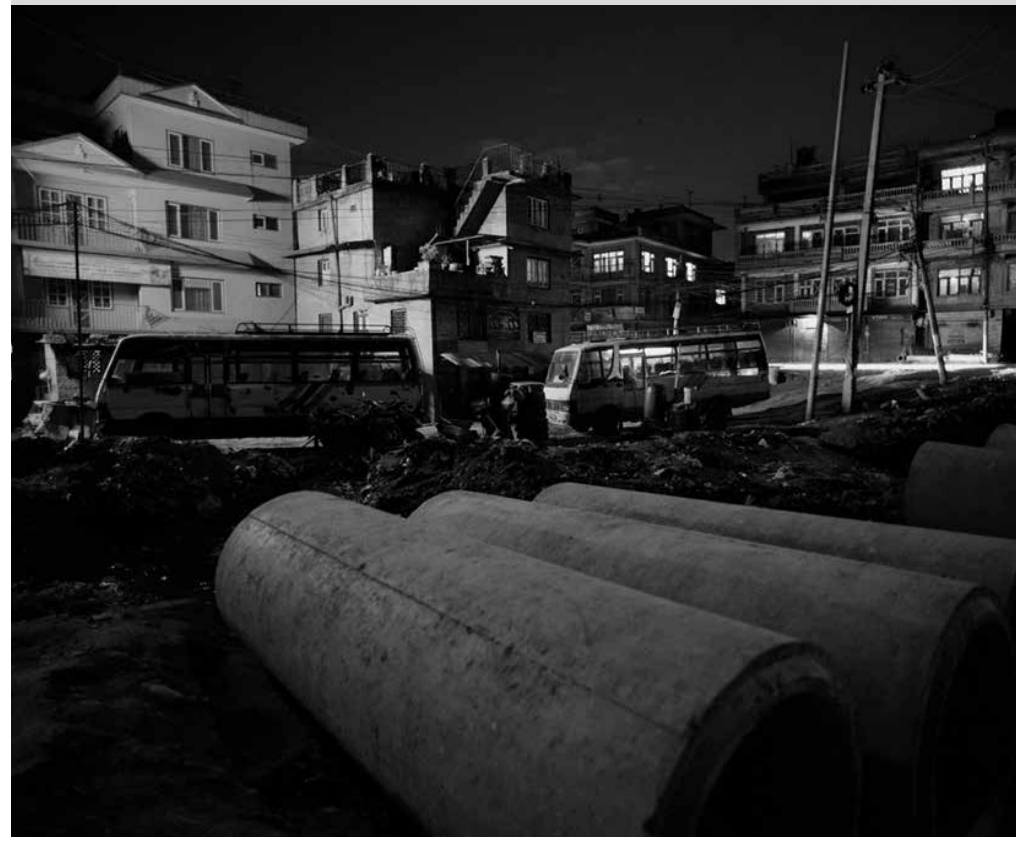


Notes on Contributors

Introduction: Beyond Aid - The Future of Development Cooperation

Jing Gu and Naohiro Kitano

Potential and Challenges for Emerging Development Partners: The Case of Indonesia

Akio Hosono

Chains of Knowledge Creation in the Evolution of New Donors

Yasutami Shimomura and Wang Ping

Estimating China's Foreign Aid Using New Data

Naohiro Kitano

Emerging Economies, Disaster Risk Reduction, and South-South Cooperation: The Case of Mexico

Neil Renwick

India's Role as a Facilitator of Constitutional Democracy

Hiroaki Shiga

Triangular Cooperation in East Asia: Challenges and Opportunities for Japanese Official Development Assistance

Jin Sato

The BRICS Effect: Impacts of South-South Cooperation in the Social Field of International Development Cooperation

Geovana Zoccal Gomes and Paulo Esteves

Perspectives on the Global Partnership for Effective Development Cooperation Xiaoyun Li, Jing Gu, Samuel Leistner and Lídia Cabral

Glossary 


\title{
The BRICS Effect: Impacts of South-South Cooperation in the Social Field of International Development Cooperation*
}

\author{
Geovana Zoccal Gomes ${ }^{1}$ and Paulo Esteves ${ }^{2}$
}

\begin{abstract}
The growing number of development stakeholders and initiatives in developing countries has added complexity to international development cooperation (IDC). Recipient countries have witnessed the increasing presence of emerging countries such as the BRICS (Brazil, Russia, India, China, and South Africa), offering South-South cooperation as an alternative model for development. We call the impact of the new practices of South-South cooperation providers on the prevailing IDC structure the 'BRICS effect' - an effect that ultimately destabilises established positions and interaction patterns between agents, and even between traditional donors and recipients. Combining the Bourdieusian notion of social fields with international relations (IR) perspectives on the changing geopolitics of international aid, this article discusses how the BRICS effect challenges established principles and practices from the field of IDC, indicating at least three dimensions: (1) new positions beyond the donor vs recipient dyad; (2) new modes of development cooperation; and (3) transformation of institutional architecture and governance mechanisms.
\end{abstract}

Keywords: South-South cooperation, development, international cooperation, Pierre Bourdieu, BRICS, OECD, DAC.

\section{Introduction}

Donors that are not members of the Development Assistance Committee (DAC) of the Organisation for Economic Co-operation and Development (OECD), also known as 'non-DAC donors' or 'emerging donors', have shaken the international aid landscape in recent years. Indeed, the footprints of emerging donors within the development cooperation landscape are becoming increasingly significant. While a United Nations Economic and Social Council report estimated that in 2006 these contributions ranged from 7.8 per cent to 9.8 per cent of all international aid, the OECD reported that non-DAC countries' contributions reached 18.7 per cent in 2014 and 
15.8 per cent in 2015 (EGOSOC 2008; OECD 2017b: 156). These figures are, at once, somewhat equivocal and highly revealing. The standards and methodologies for measuring non-DAC development cooperation contributions are extremely heterogeneous. Furthermore, many emerging donors neither report to the OECD-DAC nor share a common set of definitions or parameters. ${ }^{3}$ Development experts frequently attribute the inaccuracy of these figures to a lack of transparency on the part of emerging donors (OECD 201 lb; Ciommo 2017), but while the figures may hide the true foothold of emerging donors within the development aid system, they also reveal the erosion of the system itself. Most non-DAC countries neither identify themselves as donors nor consider their development cooperation practices as equivalent to official development assistance (ODA). ${ }^{4}$ On the contrary, most non-DAC providers identify themselves as development partners and classify their practices under the umbrella of South-South cooperation (SSG). Against this backdrop, both the act of alluding to SSC partners as 'emerging donors' and the measurement activities such as those conducted by the OECD-DAC are not so much technical exercises as political attempts to subsume SSC to the existing aid structure. Hence, rather than revealing a lack of transparency on the part of SSC partners, these attempts to frame and measure SSC under the established categories of ODA are indicative of a political dispute within the development aid landscape.

This article tries to understand how the emergence of SSC partnerships has impacted upon the field of international development cooperation (IDC). To do so, we draw on Pierre Bourdieu's sociological toolbox and the bourgeoning Bourdieu-inspired approaches in international studies to assess how the rise of new agents within a given social field may transform the structures of the field itself. ${ }^{5}$ As Richard Ashley rightly points out, Bourdieu's toolbox allows us to understand social structures like the social field of IDC as 'arbitrary and contingent effects that are imposed in history, through practice, and to the exclusion of other ways of structuring collective existence' (1989: 253). Indeed, this sociological approach serves to make inroads into understanding how emerging Southern development partners are being constituted as agents and authorised to play specific roles within a field structured, so far, around traditional donorship. Furthermore, Bourdieu's toolbox allows us to address the power struggles embedded (and hidden) within such apparently ordinary and technical activities as categorisation (e.g. emerging donors, non-DAC donors) and measurement (e.g. ODA from non-DAC donors).

The concept of the social field is our entry point for assessing the impacts of SSG partnerships on established international aid structures. A social field is composed of a number of agents that interact according to different hierarchies of power. Hence, it is under constant transformation, and IDC, when understood as a social field, is no different (Fonseca 2014; Gomes 2013). ${ }^{6}$ In this social field, the agents have well-structured positions and a specific pattern of 
relationships through which they interact with each other: official development assistance (ODA). The social relations among the agents are circumscribed by a common understanding of the rules, which can be articulated either formally or informally (Bourdieu 1990). The agents occupy hierarchical positions defined by authorised and legitimised forms of capital. Each field follows a specific logic and ascribes value to capital in distinct ways. ${ }^{7}$ It is the distribution of this capital that permits or restricts agents' capacity to exert power and influence on the field (Bourdieu 1990; Leander 2008).

We contend that in the last two decades we have witnessed growing competition, and sometimes even contestation, between established and emerging powers over their set positions. From the perspective of IDC, the emergence of SSC has decentred and transformed the practices adopted by traditional donors, moving the boundaries of the field of IDC away from the strict lines drawn up with the concept of ODA. In this article, we call the impact of SSC practices on the prevailing structures in the field of IDC the 'BRICS effect'.

The BRICS effect ultimately destabilises established positions and interaction patterns between agents, even between traditional donors and recipients. As this article tries to demonstrate, the BRICS effect comprises at least three dimensions: (1) the articulation of new positions beyond the donor/recipient dyad; (2) the induction of new modes of development cooperation; and (3) the transformation of the institutional architecture and governance mechanisms in the field of IDC. The remainder of this article comprises four sections. Section 2 presents a historical redescription of the field of IDC and the emergence of SSC in the light of Bourdieu's concepts. This is necessary to set the stage for the analysis we conduct in Section 3, in which we present the BRICS effect as an analytical tool and unpack the impacts of the rise of SSC upon the field of IDC. Finally, in Section 4 we seek to advance some preliminary conclusions, suggesting that the BRICS effect has eroded the established boundaries of the field of IDC, scrambling long-held positions and mixing development cooperation with a growing variety of development flows.

\section{The field of international development cooperation and the rise of South-South cooperation}

Even though foreign assistance activities date long before, it was only in the aftermath of the Second World War and the Bretton Woods Conference that a framework for international aid started to be drawn up. The emergence of development aid as a set of practices was conditioned by the bipolar core of the international system and by the national liberation movements at its periphery. Under these circumstances, development aid was underpinned by modernisation theories (Rostow 1960; Finnemore 1997; Rist 2008; Pieterse 2010) and became an important foreign policy tool for expanding the areas of influence of the major world powers (Antonini and Hirst 2009; Mawdsley 2012; Gu, Shankland and Chennoy 2016). Notwithstanding 
their role in advancing Western interests in general and the US liberal agenda in particular (Ruggie 1982), modernisation theories also contributed to the consolidation of spatial-temporal dynamics which ultimately enabled agency within the field of IDC (Kapoor 2008). The dichotomies of centre versus periphery and developed versus underdeveloped unfolded into the positions and roles of donor versus recipient within the field of IDC. Modernisation theories reinforced an authoritative position from which former Western imperial powers could keep a quasi-tutelary position with their former colonies (Grovogui 2001; Kothari 2005). This so-called scientific body of knowledge supported a practical belief, a 'set of instituted dogmas and doctrines' (Bourdieu 1990: 68), enabling a specific set of practices, later called official development assistance. ODA was then defined as

government aid designed to promote the economic development and welfare of developing countries. Loans and credits for military purposes are excluded. Aid may be provided bilaterally, from donor to recipient, or channelled through a multilateral development agency such as the United Nations or the World Bank. Aid includes grants, 'soft' loans (where the grant element is at least 25\% of the total) and the provision of technical assistance. The OECD maintains a list of developing countries and territories; only aid to these countries counts as ODA (OECD 2015).

The establishment of ODA set the boundaries of the field of IDC, distinguishing its specific practices from other economic flows, such as trade or investments. Furthermore, the concept of ODA fixed the hierarchical positions of donor and recipient within the same field. A 'stage of development' became a vantage point from which donors could assert what policies and development paths were right for the 'less developed' recipient countries. The donorship credo embraced a notion of responsibility in which 'advanced' or 'industrialised' economies became responsible for international development and for promoting 'economic development and welfare of developing countries'. Bourdieu has called this kind of practical belief 'doxa'. Doxa ultimately enables agency, generates classificatory schemas, structures positions, and guides practices, which become naturalised over time (Bigo 2011). The donorship doxa was gradually taken for granted and ODA became its main doxic practice. ${ }^{8}$ Moreover, the donorship doxa transformed a contingent and arbitrary choice into a necessary requirement, thereby excluding other policy options which did not follow the generally accepted credo. Considering that objective relations structure the social field and the positions occupied by agents, it is possible to argue that the field of IDC was consolidated when this system of oppositions between 'developed' and 'underdeveloped' gained force (Mawdsley 2012).

Doxa refers to the specific experience of the moment when objective order and subjective organisational principles are in a quasi-perfect correspondence, making the natural world and the social world seem self-evident. It represents an absolute recognition of legitimacy, 
without, however, any recognition of arbitrariness, and generates a spontaneous and widely held idea of what is taken for granted. In this logic, unspoken knowledge is what constitutes social reality, meaning the fundamental structures of a social field which themselves exercise a sort of structural power over the practices within the field. The field of IDC is therefore organised around the donorship doxa, which establishes specific positions, responsibilities, and roles for developed and developing countries as either donors or recipients. ODA has become the key practice within the field, bringing together donors and recipients around the development credo. Through the strategic mobilisation of the forms of capital at stake, the agents engage in a constant battle for the doxa of a specific field (Guzzini 2000; Bourdieu 1977; Berling 2012).

The institutional structure of the field of IDC has also followed the donorship doxa. Indeed, since the 1960s the frontiers and practices of the field have been defined by a small group of key donors, members of the DAC. The DAC was built from an earlier institution, the Development Assistance Group (DAG), when the OECD was created. DAG was a consultation forum established in early 1960 among the main donors under the leadership of the USA during the Dwight D. Eisenhower administration. DAC replaced DAG in September 1961 with the main goal of defining and monitoring global patterns of international development in key areas.

Donation within the framework of ODA, performed along the North-South axis, has become the normal and expected behaviour of a developed country within the field of IDC. Nevertheless, the consolidation of this field is itself the result of a doxic battle. Indeed, as seen above, while donorship might be considered a by-product of the Cold War and a fixture at the heart of the international system, it was also a response for the national liberation movements that were mushrooming at the periphery. These movements not only defied colonial rule but also challenged the structural inequalities which underpinned donorship practices. ${ }^{9}$ At the periphery, Southern countries articulated a new narrative around the concepts of individual and collective self-reliance, emphasising autonomy or self-determination and non-intervention as key dimensions of development cooperation. This SSC narrative was articulated both as a political tool to reinforce national liberation movements and as an alternative to the emerging donorship doxa. Although the burgeoning field of IDC was structured around this doxa, it was challenged from inside by Southern countries keen to assert two new modes of development cooperation: Technical Cooperation among Developing Countries and Economic Cooperation among Developing Countries, both under the umbrella of SSC, as discussed below. Furthermore, while the donorship doxa articulated Southern countries' positions as recipients, the SSC narrative was a way for them to renegotiate their positions in the field of IDC, setting the limits of the donorship doxa while calling for more horizontal patterns of relationship. 
Keen to enhance their capital and maximise their interests (whether symbolic or material) in the international arena, countries from the global South began to articulate their own strategies and initiatives, envisioning more autonomous avenues towards development: the Non-Alignment Movement, the launch of the United Nations Conference on Trade and Development (UNCTAD) and the United Nations Development Programme (UNDP), the inception of the G77 and the Declaration on the Establishment of a New International Economic Order (Mawdsley 2012; Esteves and Assunção 2014; Toye 2014). The tensions between developed and developing countries gave rise to the North-South debate, through which the global South aimed to expand its influence on the rules of the international order (Hurrel and Woods 1999; Woods 1999). Under the umbrella of UNDP, the Buenos Aires Action Plan (1978) focused on the promotion and implementation of technical cooperation among developing countries, forming the first framework in which the term 'horizontal cooperation' was used, as opposed to the vertical notion of cooperation that traditionally predominated in North-South cooperation (UN 1978; UNDP 1994; Mawdsley 2012; Gu 2017). While the Buenos Aires Action Plan consolidated Technical Cooperation among Developing Countries as one form of SSC, the G77 recognised Economic Cooperation among Developing Countries in 1981 at the Caracas Programme of Action on Economic Cooperation among Developing Countries as another legitimate practice for fostering development among Southern countries (UN 1978; G77 1981). Even if SSC partners lacked the material capacities to implement these programmes in any significant way, the establishment of these modes of cooperation became a landmark in the field of IDC, stressing the differences between hierarchical donorship practices and the supposedly horizontal forms of SSC.

The 2000s witnessed a weakening of the imposition of conditionalities. The demise of the Washington Consensus accompanied the rise of new powers, such as China and India. In this context, policies favouring structural reforms lost ground. Moreover, even while recognising that gross domestic product (GDP) growth was an important component of development policies, new agents in the field were keen to stress the need to expand the development agenda (Stiglitz 2003). Dissatisfied with many of the results of ODA, middle-income countries kept up the pressure for increased participation and involvement for Southern countries in the field of IDC.

The Paris Declaration may be seen as an attempt to rebuild the field's boundaries in a context of increasing contestation and declining legitimacy of donors' practices (Esteves and Assunção 2014). Indeed, the final document of the second High Level Forum on Aid Effectiveness, which took place within the scope of the OECD, introduced the principles of harmonisation, alignment, and coordination as essential for the effectiveness of international aid. The declaration stressed the principle of ownership, highlighting the ways donors and recipient countries relate to each other (OECD 2008). 
Even with greater emphasis on the principle of ownership, the donorship doxa was not able to redress structural asymmetries and the power games played among donors and recipients. For many developing countries, donors' practices were still seen as ways to influence or impose a predetermined agenda on recipient countries or even smaller donors (Eyben 2010). In this context, SSC was put forward as an alternative way to foster development - a set of practices free from conditionalities and based upon horizontal and mutually beneficial results.

Despite the growing relevance of SSC, it was only in 2008, at the High Level Forum (HLF) on Aid Effectiveness in Accra (Accra HLF), that these practices were recognised as a constitutive and legitimate part of the field of IDC. The Accra Agenda for Action recommended that developing countries should strengthen their capacity to conduct and manage development through strong institutions and local expertise, counting not only on traditional cooperation, but also on SSC, which was recognised as 'a valuable complement to North-South co-operation’ (OECD 2008: 18).

\section{The BRICS effect}

During the 2000s, rising powers started to play an increasingly important role within the field of IDC. Their main impact on the field was the recognition of $\mathrm{SSC}$ as a legitimate set of practices. While the Accra HLF mentioned SSG for the first time, the Nairobi outcome document of the High-level UN Conference on South-South Cooperation re-established the principles of SSC in line with the concepts set forth in the Paris Declaration. If, as discussed above, the Paris Declaration can be seen as a response to the eroding legitimacy of donor practices (particularly conditionalities) and to the rise of new donors, the Accra HLF and the Nairobi outcome document constitute an attempt to introduce SSC partnerships into the donorship doxa. From Accra and Nairobi on, the effects of the rise of SSC within the field of IDC became more acute.

We call these movements of competition and differentiation within the field of IDC the BRICS effect. ${ }^{10}$ This analytical tool allows us to understand the multidimensional impacts generated by the rise of SSC in the field and the interplay between two distinct but articulated dynamics: competition and differentiation. For Bourdieu, competition struggles are not designed to transform the principles, but to modify the positions of the agents in the field. Struggles for differentiation, on the other hand, are aimed at transforming the current legitimate definition of reality in a given field, subverting the established order (Bourdieu 1990). By emphasising an alternative set of principles, SSC partnerships do not compete to occupy established positions; indeed, they generate an original narrative in which different positions are articulated. Meanwhile, the attempts by traditional donors to bring SSC into the established structure of the field indicate a struggle to establish a competitive environment, where traditional donors and agents of SSC play under the same rules. In any case, the interplay between 
competition and differentiation decentres the entire field, challenging the donorship doxa, displacing the monopolistic position of traditional donors at its core and multiplying the practices considered legitimate by its agents. Hence, the BRICS effect is a multidimensional phenomenon, comprising: (1) the articulation of new positions beyond the donor vs recipient dyad; (2) the induction of new modes of development cooperation; and (3) the transformation of the institutional architecture and governance mechanisms in the field of IDC.

The creation of the Global Partnership for Effective Development Co-operation (GPEDG) is the most important outcome of the rising powers' foothold in the field of IDC. It was established at the fourth HLF on Aid Effectiveness, held in 2011 in Busan, South Korea (OECD 2011 a). Reinforcing the importance of SSG agents, the meeting addressed the need to enlarge the participation of the various actors and practices in the field of IDC, highlighting at the same time the principle of 'common but differentiated responsibilities'. The main priority of the GPEDC was the inclusion and representativeness of emergent actors. The Busan Forum may be seen as the 'beginning of the end' of a development governance controlled by the West (Mawdsley 2012).

Nevertheless, it is necessary to bear in mind that despite claiming common principles for a new model of international cooperation such as non-interference in internal matters, no conditionalities, and a demand-driven approach - SSC is not a homogeneous set of practices. As early as 2006, Richard Manning, former president of OECD-DAC, presented an effort to map out the diversity among the agents of SSC. During a lecture at the UK Overseas Development Institute, he presented four categories of emerging donors: (1) OECD members that are not part of DAC, such as Mexico; (2) new EU members, who are not part of the OECD; (3) Middle Eastern countries which are members of the Organization of the Petroleum Exporting Countries (OPEC); and (4) emerging donors that are not members of OECD, such as Brazil, China, and India (Manning 2006).

New EU members are not opposed to the current international aid system, and are looking forward to joining it, not reforming it. Arab donors have their own model, which does not correspond to but also does not cast into question the practices of OECD-DAC. Hence, the tensions over the boundaries of the field of IDC and its doxa are caused by the struggle of those disputing the DAC model: the fourth group demarcated by Richard Manning.

These countries position themselves as providers of a different model of development assistance, a model based on more equal partnerships that encompass not only technical and financial assistance, but also strengthened trade and investment, and on the sharing of knowledge and experiences that are closer to, and more relevant for, the low-income countries that they provide assistance to (de Renzio and Seifert 2014: 1865). 
The cleavage between the OECD-based GPEDC and the United Nations Development Cooperation Forum is indicative of a process of differentiation within the field of IDC. New development cooperation providers from outside the OECD which do not identify themselves with the donor position tend to question the legitimacy of the Global Partnership. This group of new providers has put pressure on the frontiers of the field while establishing new flows of expertise, goods, and investments as legitimate practices. Northern donors are no longer alone, and ODA is no longer the only legitimate form of development assistance. While emerging powers have exerted external pressure to establish their positions and consolidate their practices, traditional donors have seen their monopolistic positions challenged and the borders of the field disputed. This has led to an effort advanced by the OECD-DAC to attract the new agents, SSC practitioners, to its own umbrella of common practices, specifically those involving quantification, monitoring, evaluation, and the Aid Effectiveness agenda.

On the one hand, OECD-DAC has established mechanisms such as the China-DAC study group in a bid to share its own practices with new agents. On the other, traditional donors such as the UK and Germany have modified their own strategies towards emerging countries, introducing new triangular cooperation programmes. It is possible to regard both of these strategies as forms of advocacy designed to align the new practices and modalities with the Aid Effectiveness agenda and to co-opt Southern agents to adjust their actions to the traditional practices from the field of IDC. This situation would seem to confirm the theoretical assumption that new agents should adapt to existing norms within the field.

These attempts to co-opt emerging countries into traditional practices can be observed in various fields, such as the climate change agenda. The failure of the Kyoto Protocol is allegedly due to the unwillingness of emerging countries to shoulder their burden of responsibility for mitigation or adaptation. The final document from COP 21, the Paris Agreement, itself builds on a bottom-up methodology, allowing countries to join efforts to address climate change, spreading the burden of mitigation and adaptation beyond just industrialised countries.

Another example from the development agenda is the construction of the Sustainable Development Goals (SDGs), based on the principle of universality. Oddly, UN Resolution A/RES/70/1, which outlines the 2030 Agenda for Sustainable Development, reaffirms the principle of common but differentiated responsibilities. Nevertheless, departing from the principle of universality, the SDGs set international goals to be met by all countries, not only from the developing world. This suggests that 'we are all developing countries now' (Esteves 2017) and that developed and developing countries must share responsibility for climate change and development. 
While there seems to be a trend for the agents of SSC to adapt to the established doxa of the field of IDC, the actual practices and doxa of the field are themselves in flux. The notion of differentiation developed by Bourdieu thus appears to be the second effect brought by the increasingly strengthened agency of the BRICS in the field. Different agents are starting to develop their own patterns to deal with international development, eroding the entire field.

The concept of ODA put agents in the position of donors or recipients, where donors had responsibilities towards recipient countries and international development, demarcating the legitimised practices of the field. In October 1970, the UN called for countries to allocate 0.7 per cent of their gross national income (GNI) to ODA. However, very few countries have actually reached this goal. According to 2017 data, Norway, Luxemburg, Sweden, Denmark, and the UK are the only countries allocating 0.7 per cent or more of their GNI to ODA. Moreover, the DAC members' net ODA represented 0.31 per cent of their total GNI (OECD n.d.), one of the highest levels since 2005.

Nevertheless, this concept has been transformed over time and has lost ground in recent years. There has been an attempt to stretch the concept of ODA, which has also come to be understood as a flow that allows donors to invest in public-private partnerships, for instance, in order to lessen the risks of private investment in developing countries. Also, in-donor expenditure on refugees beyond the one-year term normally imposed has been included in calculations of ODA (Esteves 2017). Related to the dwindling importance of ODA, the struggle by emerging countries for differentiation can be observed in the formulation of a new statistical measurement framework, the Total Official Support for Sustainable Development (TOSSD). TOSSD is based on the notion of measuring all development flows contributing to sustainable development, which include private investments and non-concessional loans, making ODA just one of many other flows contributing to the achievement of the SDGs (Besharati 2017).

Surprisingly, the TOSSD proposals include the principle of mutual benefits, which is one of the SSC principles defined in the 2009 Nairobi Declaration, and which has been highly criticised by many traditional donors as a way of doing business under a rhetoric of fostering development. This indicates a remarkable transformation in the practices and doxa of the field, as traditional donors are having to adapt to new modes of behaviour put forward by emerging countries and SSC agreements, and not the other way around.

\section{Concluding remarks: is the field of IDC in decline?}

After decades of prominent discourse about development, there is no more place for innocence (Ribeiro 2007: 275).

Particularly since the end of the 1990s, the field of IDC has become a true battlefield (Esteves and Assunção 2014) in which the Western-centric 
discourse on international development, grounded strongly in a belief in linear progress, has been questioned and defied. The purposes and practices considered legitimate by the ODA framework since its demarcation by the OECD-DAC are no longer seen as being as representative and credible as they were when it was first defined.

At the beginning of the 2000s, development agents had to deal with an increasingly contested field. Both the donor positions and the practices of donorship were disputed. In addition, the fundamental goals of development policies and the ways to achieve them became problematic... This doxic battle had a germane effect on the field, since it drew attention to its borders, problematising what would be considered legitimate practices within the international development field (Esteves and Assunção 2014: 1781).

Traditional donors now need to accommodate the major new forces operating in the field of IDC. If there ever was a clear division between developed and underdeveloped, or donor and recipient, which determined the zones of dominance in the field, now this distinction is significantly blurred. Moreover, new agents such as transnational social movements and the private sector have been incorporated into the field. Interestingly, these transformations in the configuration of the capital and relative positions in the field have not only been seen between traditional and emerging donors.

At the same time as the borders and doxa of the field of IDC have been challenged, the legitimacy of the agency of Southern actors has also been contested. Domestically, many of these countries still face struggles against poverty and inequality, making it hard for them to justify their new international role to their own people. Internationally, although they have devised joint strategies that have put pressure on the current order, these agents do not form a homogeneous or cohesive group.

Countries such as Mexico or South Korea, despite positioning themselves as agents of SSC, have joined the OECD and adopted its principles. This group are in a competitive struggle to increase their capital, but are not yet in a position to contest the status quo. Meanwhile, countries such as Brazil and India have repeatedly stood up against the traditional principles of cooperation. In a bid for differentiation, they are keen to challenge the value of the prevailing forms of capital, practices, and borders in the field of IDC. ${ }^{11}$

Analyses focusing on struggles in the field of IDC indicate that the consolidation of SSC has brought to the fore considerable tension over the frontiers of and practices in the field. As the analysis of the BRICS effect has revealed, these tensions are manifested at the same time in terms of positions, practices, and institutional arrangements. The historical redescription shows that the practical logics, the configuration of capital relevant to the field, and the relative positions occupied by agents have been in constant transformation since the first time 
the boundaries of the doxa in the field of IDC were set. Considering Bourdieu's $(1977,1990)$ indication that doxa is a quasi-perfect correspondence between the objective order and the subjective organisational principles of a social field, and bearing in mind that the field of IDC has been marked by a trajectory of constant tussles over its guiding principles, it is worth questioning whether or not the agents within the field will be able to keep its borders any wider than the doxa of donorship.

The field of IDC was consolidated under the dichotomy of developed versus developing countries, positioning agents as either donors or recipient countries. The positions the countries occupy in the field and the amount and type of capital they possess also inform the received assumptions about the practices in the field. This is what gives agents the authority to act and lay down the rules of the field for some but not for others.

The presence of SSC agents that do not follow traditional practices has put some strain on the doxa and stretched the boundaries of the field. The demand for an alternative, such as the creation of new multilateral banks, indicates that the field has become decentred. In 2016, global ODA was worth a total of US\$142.6bn, its highest level since the turn of the twenty-first century (OECD 2017a). Nevertheless, if the SDGs are to be reached, cooperation must rise from billions to trillions, but this can only be done if private investments are brought into play. Hence, contrary to what might have been expected - that new agents would adapt to the existing framework as they jockeyed for positions in the field - what is actually happening is that traditional donors are adapting to the ways of Southern agents and the new approaches they have introduced.

\section{Notes}

* This article was produced as part of the project 'Brazil, the BRICS and International Cooperation for Development' funded by the Rio de Janeiro state funding agency, FAPERJ (CNE E-26/201.386/2014), with additional support from the Brazilian postgraduate education and research agency, CNPq. Previous versions were presented at the Development Studies Association 2016 Annual Conference and at an IDS Members' Seminar in 2017.

1 Geovana Zoccal Gomes is a $\mathrm{PhD}$ candidate at the Institute of International Relations, Pontifical Catholic University of Rio de Janeiro (IRI/PUC-Rio), Brazil, and a researcher at the BRICS Policy Center, Rio de Janeiro, Brazil.

2 Paulo Esteves is an Associate Professor at the Institute of International Relations, Pontifical Catholic University of Rio de Janeiro (IRI/PUC-Rio), Brazil, Director of the BRICS Policy Center, Rio de Janeiro, Brazil, and Fellow at the Institute for Advanced Sustainability Studies, Potsdam, Germany.

3 For a comprehensive review of existing definitions and methods, see Silva et al. (2016). 
4 Given the differences between DAC and non-DAC countries, the latter are currently trying to develop their own standards for measuring development cooperation. See Corrêa (2017).

5 On the value added by Bourdieu-inspired approaches in international studies, see Berling (2012), Leander (2008), and Guzzini (2006).

6 The social field is a sphere of action, a locus of social phenomena, a structured and abstract space of social positions, a space in which agents occupy distinct positions in relation to one another. It is organised around structuring axes that constitute the space of related defined positions; i.e. agents' social positions are defined in accordance with their relations (Bourdieu 1990). The field allows the social world to be divided into sub-systems, which are to some extent autonomous in their own logical practices, the result of a historical process of autonomisation. To analyse situations happening in the field it is necessary to first analyse the field itself. Nevertheless, autonomy should not be seen as a synonym of independence or an a priori fact. It is first and foremost a methodological principle grounded in the assumption that it is necessary to empirically define an object of study. The field always exists in a context involving other fields and its logic will be continually influenced by other fields' logics (Criado 2008; Leander 2008).

7 Each field ascribes different values to different kinds of capital, following a specific logic defined by the field. Capital may be material, like private property, economic capital, or a degree, but it can equally be symbolic, collectively recognised and authorised (Bourdieu 1990).

8 On doxic practices, see Guzzini (2006) and Leander (2008).

9 Dependency theory, for instance, emerged in the 1960s, and drew attention to the imperial exploitation of the periphery and the reproduction of structural inequalities. Despite its self-centred (nationalistic) perspective on accumulation, dependency theory agrees with economic development and capital accumulation. It was the alternative development thinking of the 1970s that assimilated 'human flourishing', focused on social and collective development (Pieterse 2010).

10 Rather than referring to the BRICS countries or BRICS as a group, the BRICS effect alludes to a general perception of the end of the unipolar moment and the establishment of alternative poles of power, economic dynamism, and normative entrepreneurship.

11 One reflex of this dispute is the aforementioned engagement in the Global Partnership. While Southern countries that are OECD members defend participation in the GPEDG, agents such as Brazil identify the United Nations Capital Development Fund (UNDCF) as the legitimate forum, as it is under the UN system ( $c f$. Esteves and Assunção 2014). 


\section{References}

Antonini, B. and Hirst, M. (2009) Pasado y presente de la cooperación Norte-Sur para el desarrollo, Buenos Aries: Ministry of Foreign Affairs, International Trade and Worship, Republic of Argentina

Ashley, R.K. (1989) 'Imposing International Purpose: Notes on a Problematic of Governance', in E.O. Czempiel and J.N. Rosenau (eds), Global Changes and Theoretical Challenges: Approaches to World Politics for the 1990s, Lexington MA: Lexington Books

Berling, T.V. (2012) 'Bourdieu, International Relations, and European Security', Theory and Society 41.5: 451-78

Besharati, N. (2017) 'New Development Finance Measure should be TOSSD out the Window!', SAIIA Policy Insights 45

Bigo, D. (2011) 'Pierre Bourdieu and International Relations: Power of Practices, Practices of Power', International Political Sociology 5.3: 225-58

Bourdieu, P. (1990) The Logic of Practice, trans. by Richard Nice, Cambridge: Polity Press

Bourdieu, P. (1977) Outline of a Theory of Practice, trans. by Richard Nice, Cambridge: Cambridge University Press

Ciommo, M.D. (2017) Approaches to Measuring and Monitoring South-South Cooperation, Development Initiatives Discussion Paper, Bristol: Development Initiatives

Corrêa, M.L. (2017) 'Quantification of South-South Cooperation and its Implications to the Foreign Policy of Developing Countries', South Centre Policy Brief 41, Geneva: South Centre

Criado, E.M. (2008) 'El concepto de campo como herramienta metodológica', Revista Española de Investigaciones Sociológicas (Reis) 123: 11-33

de Renzio, P. and Seifert, J. (2014) 'South-South Cooperation and the Future of Development Assistance: Mapping Actors and Options', Third World Quarterly 35.10: 1860-875

ECOSOC (2008) Trends in South-South and Triangular Development Cooperation: Background Study for the Development Cooperation Forum, New York NY: United Nations Economic and Social Council

Esteves, P. (2017) 'Agora somos todos países em desenvolvimento? A Cooperação Sul-Sul e os ODS', Pontes: International Centre for Trade and Sustainable Development 13.2

Esteves, P. and Assunção, M. (2014) 'South-South Cooperation and the International Development Battlefield: Between the OECD and the UN', Third World Quarterly 35.10: 1175-790

Eyben, R. (2010) 'Harmonisation: How is the Orchestra Conducted?', in A. Cornwall and D. Eade (eds), Deconstructing Development Discourse: Buzzwords and Fuzzwords, Rugby: Practical Action Publishing

Finnemore, M. (1997) 'Redefining Development at the World Bank', in F. Cooper and R. Packard (eds), International Development and the Social Sciences: Essays on the History and Politics of Knowledge, Berkley and Los Angeles CA: University of California Press

Fonseca, J.M. (2014) 'A Cooperação Sul-Sul e o Campo da Cooperação Internacional para o Desenvolvimento: um estudo de caso sobre 
Moçambique e dependência simbólica', MSc thesis, International

Relations, Pontifical Catholic University of Rio de Janeiro (PUC-Rio)

G77 (1981) Programme of Action Adopted at the High-Level Conference on

Economic Cooperation Among Developing Countries (ECDC), Caracas, 13-19 May 1981

Gomes, G.Z. (2013) 'Brasil e o subcampo da CSS: As práticas brasileiras na cooperação agrícola entre Embrapa-ABC e Moçambique', MA thesis, International Relations, Pontifical Catholic University of Rio de Janeiro (PUG-Rio)

Grovogui, S. (2001) 'Sovereignty in Africa: Quasi-Statehood and Other Myths in International Theory', in K. Dunn and T. Shaw (eds), Africa's Challenge to International Relations Theory, London: Palgrave Macmillan

Gu, J. (2017) 'China and the Emerging Economies', in P. Haslam, J. Schafer and P. Beaudet (eds), Introduction to International Development: Approaches, Actors and Issues, 3rd ed., Oxford: Oxford University Press

Gu, J.; Shankland, A. and Chenoy, A. (eds) (2016) The BRICS in International Development, London: Palgrave Macmillan

Guzzini, S. (2006) 'Applying Bourdieu's Framework of Power Analysis to IR: Opportunities and Limits', paper presented at the 47th Annual Convention of the International Studies Association, Chicago, 22-25 March, http://citeseerx.ist.psu.edu/viewdoc/ download?doi=10.1.1.531.2260\&rep $=$ repl\&type $=$ pdf $($ accessed 25 April 2018)

Guzzini, S. (2000) 'A Reconstruction of Constructivism in International Relations', European Fournal of International Relations 6.2: 147-82

Hurrel, A. and Woods, N. (1999) 'Introduction', in A. Hurrel and N. Woods (eds), Inequality, Globalization, and World Politics, New York NY: Oxford University Press

Kapoor, I. (2008) The Postcolonial Politics of Development, London: Routledge Kothari, U. (2005) A Radical History of Development Studies: Individuals, Institutions and Ideologies, London: Zed Books

Leander, A. (2008) 'Thinking Tools', in A. Klotz and D. Prakash (eds), Qualitative Methods in International Relations: A Pluralist Guide, Basingstoke and New York NY: Palgrave Macmillan

Manning, R. (2006) 'Will "Emerging Donors" Change the Face of International Cooperation?', ODI Lecture, What's Next in International Development?, 9 March, www.odi.org/events/156-willemerging-donors-change-face-international-cooperation (accessed 19 April 2018)

Mawdsley, E. (2012) From Recipients to Donors: Emerging Powers and the Changing Development Landscape, London: Zed Books

OECD (2017a) Development Aid Rises Again in 2016, The Development Assistance Committee: Enabling Effective Development, 11 April, www.oecd.org/dac/financing-sustainable-development/ development-finance-data/ODA-2016-detailed-summary.pdf (accessed 12 September 2017)

OECD (2017b) Development Co-operation Report 2017, Paris: Organisation for Economic Co-operation and Development 
OECD (2015) Distribution of Net ODA, OECD Data, https://data.oecd. org/oda/distribution-of-net-oda.htm (accessed 4 August 2015)

OECD (201 la) Busan Partnership for Effective Development Co-operation, Fourth High Level Forum on Aid Effectiveness, Busan, Republic of Korea, 29 November-1 December, www.oecd.org/dac/ effectiveness/49650173.pdf (accessed 19 April 2018)

OECD (2011b) Unlocking the Potential of South-South Cooperation: Policy Recommendations from the Task Team on South-South Cooperation, Paris: Task Team on South-South Cooperation, Organisation for Economic Co-operation and Development

OECD (2008) The Paris Declaration on Aid Effectiveness and the Accra Agenda for Action, Paris: Organisation for Economic Co-operation and Development

OECD (n.d.) 'Official Development Assistance 2017: ODA 1960-17 Trend', Compare Your Country, www2.compareyourcountry.org/ oda?cr $=20001 \& \mathrm{cr} 1=$ oecd\&lg=en\&page $=1($ accessed 12 September 2017)

Pieterse, J. (2010) Development Theory: Deconstructions/Reconstructions, 2nd ed., London: Sage Publications

Ribeiro, G.L. (2007) 'Poder, Redes e Ideologia no campo do desenvolvimento', in K.C. Silva and D.S. Simião (eds), Timos-Leste por trás do palco: Cooperação Internacional e a dialética da formação do Estado, Belo Horizonte: UFMG

Rist, G. (2008) The History of Development: From Western Origins to Global Faith, 3rd ed., London and New York NY: Zed Books

Rostow, W. (1960) The Stages of Economic Growth: A Non-Communist Manifesto, New York NY: Cambridge University Press

Ruggie, J.G. (1982) 'International Regimes, Transactions, and Change: Embedded Liberalism in the Postwar Economic Order', International Organization 36.2: 379-415

Silva, D.M.; Suyama, B.; Pomeroy, M. and Santos, V.S. (2016) Panorama do Monitoramento dos Fluxos da Cooperação Internacional para o Desenvolvimento: Oportunidades e Desafios para a Construção de uma Metodologia Brasileira, São Paulo: Articulação Sul

Stiglitz, J. (2003) 'Towards a New Paradigm of Development', in J.H. Dunning (ed.), Making Globalization Good: The Moral Challenges of Global Capitalism, New York NY: Oxford University Press

Toye, J. (2014) 'Assessing the G77: 50 Years after UNCTAD and 40 Years after the NIEO', Third World Quarterly 35.10: 1759-774

UN (1978) Report of the United Nations Conference on Technical Co-operation among Developing Countries: Buenos Aires 30 August to 12 September 1978, A/CONF.79/13/Rev.1, New York NY: United Nations Publications

UNDP (1994) The Buenos Aires Plan of Action, New York NY: Special Unit for TCDC, United Nations Development Programme

Woods, N. (1999) 'Order, Globalization, and Inequality in World Politics', in A. Hurrell and N. Woods (eds), Inequality, Globalization, and World Politics, New York NY: Oxford University Press 